MaPan : Jurnal Matematika dan Pembelajaran

p-ISSN: 2354-6883 ; e-ISSN: 2581-172X

Volume 7, No 2, December 2019 (342-358)

DOI: https://doi.org/10.24252/mapan.2019v7n2a12

\title{
PENGEMBANGAN BUKU KERJA PERSAMAAN DIFERENSIAL BIASA PADA MAHASISWA PROGRAM STUDI PENDIDIKAN MATEMATIKA FKIP UNISMUH MAKASSAR
}

\author{
Andi Alim Syahri1), Sri Satriani'2), Ma'rup ${ }^{3)}$, Erni Ekafitria Bahar ${ }^{4)}$ \\ 1,2,3,4Universitas Muhammadiyah Makassar \\ 1,2,3,4 J1. Sultan Alauddin No.259, Gn. Sari, Sulawesi Selatan \\ E-mail: andialims@unismuh.ac.id ${ }^{1}$, , srisatriani@unismuh.ac.id ${ }^{2)}$ \\ maruf.mtk02@gmail.com $^{3}$, erniekafitria@unismuh.ac.id ${ }^{4}$ )
}

Submitted: 06-11-2019, Revised: 14-12-2019, Accepted: 15-12-2019

\begin{abstract}
Abstrak:
Penelitian ini bertujuan untuk mengetahui proses pengembangan Buku Kerja persamaan diferensial pada mahasiswa Program Studi Pendidikan Matematika FKIP Unismuh Makassar Tahun Ajaran 2019/2020. Prosedur penelitian dalam mengembangkan Buku Kerja berdasarkan pengembangan yang dipaparkan oleh Bord \& Gall terdiri dari 8 langkah, yaitu: (1) pengumpulan informasi; (2) perencanaan; (3) pengembangan desain produk; (4) validasi desain produk; (5) revisi produk; (6) uji coba produk; (7) revisi produk; dan (8) produksi Buku Kerja. Dari hasil penelitian diperoleh validitas RPS dan Buku Kerja yang dikembangkan. Berdasarkan hasil penilaian 2 validator, diperoleh nilai rata-rata total validitas Rencana Pembelajaran Semester (RPS) sebesar 3,78 dan termasuk dalam kategori "Sangat Valid". Nilai ratarata total validitas Buku Kerja sebesar 3,60 dan termasuk dalam kategori "Sangat Valid", sehingga Rencana Pembelajaran Semester dan Buku Kerja ini dinyatakan memenuhi kriteria validitas dan dapat digunakan dengan sedikit revisi. Uji coba produk Buku Kerja kepada mahasiswa bertujuan untuk mengetahui kemenarikan produk Buku Kerja dan diperoleh skor rata-rata sebesar 3,61 berada pada kategori "Sangat Menarik". Oleh karena itu, dapat disimpulkan bahwa produk Buku Kerja layak digunakan, khususnya pada mahasiswa Program Studi Pendidikan Matematika FKIP Universitas Muhammadiyah Makassar.
\end{abstract}

Kata Kunci: Pengembangan, Borg \& Gall, Buku Kerja, Persamaan Diferensial

\section{DEVELOPING STUDENT BOOK OF DIFFERENTIAL EQUATION IN MATHEMATICS EDUCATION DEPARTMENT OF FKIP UNISMUH MAKASSAR}

\begin{abstract}
s:
The purpose of this research was to know the development process of student exercise book of differential equation in Mathematics education department of FKIP Unismuh Makassar academic year 2019/2020. The research procedures in developing of student exercise book based on Bord $\mathcal{E}$ Gall which consisted of 8 steps, namely: (1) collecting information; (2) planning; (3) developing the design product; (4) validating the design product; (5) revising the product;
\end{abstract}


(6) testing; (7) revising; dan (8) producing exercise book. The result indicated that RPS (semester lesson plan) and the student exercise book base on 2 validators' assessment were valid. The findings showed that the mean score of RPS was 3.78 which was categorized "very valid" and exercise book gained 3.60, also in "very valid" criteria. The findings indicated that RPS and exercise book fulfilled the validity criteria and were eligible to use with a little revision. While the product was tested to the students to find how interested the exercise book. Generally, the mean score gained was 3.61 which included in "very interesting" criteria. Therefore, the exercise book was eligible to use especially to the students of Mathematics education of FKIP Muhammadiyah university in Makassar.

Keywords: Development, Borg \& Gall, Exercise Book, Differential Equation

How to Cite: Syahri, A. A., Satriani, S., Ma'rup, \& Bahar, E. E. (2019). Pengembangan Buku Kerja persamaan diferensial biasa pada mahasiswa program studi pendidikan matematika FKIP Unismuh Makassar. MaPan: Jurnal Matematika dan Pembelajaran, 7(2), 342-358.

\section{PENDAHULUAN}

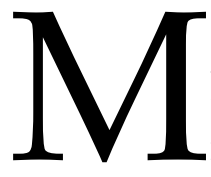

ata kuliah persamaan diferensial biasa merupakan salah satu mata kuliah yang dipelajari di perguruan tinggi. Mata kuliah ini adalah mata kuliah wajib yang harus dipelajari dengan total 3 SKS oleh mahasiswa program studi pendidikan matematika. Menurut Diprima dalam Lumbantoruan (2019), persamaan diferensial adalah persamaan matematika untuk fungsi satu variabel atau lebih, yang menghubungkan nilai fungsi itu sendiri dan turunannya dalam berbagai orde. Persamaan diferensial memegang peranan penting dalam rekayasa, fisika, ilmu ekonomi dan berbagai macam disiplin ilmu. (Ibnas, 2017). Mata kuliah ini cukup strategis karena berkaitan dengan bagian-bagian sentral dalam matematika seperti dalam analisis, aljabar, geometri, dan yang lainnya yang akan sangat berperan dalam pengenalan konsep maupun pemecahan masalah yang berkaitan dengan dunia nyata. Untuk memformulakan ke dalam bentuk matematika mensyaratkan fungsi yang memenuhi persamaan yang memuat satu atau lebih turunan-turunan dari fungsi yang diketahui.

Menurut Sugiyarto (2014), persamaan diferensial adalah satu persamaan yang terdapat atau diferensial satu atau lebih variabel tak bebas terhadap satu atau lebih variabel bebas. Untuk itu, persamaan diferensial harus dikuasai oleh setiap calon guru matematika. Namun di lapangan, peneliti menemukan bahwa kemampuan mahasiswa dalam memahami persamaan diferensial masih relatif rendah. Kenyataan menunjukkan bahwa 
mata kuliah persamaan diferensial pada umumnya kurang disenangi oleh mahasiswa program studi matematika. Hal ini dilihat dari hasil penilaian akhir semester Program Studi Pendidikan Matematika semester IV tahun ajaran 2018/2019 masih relatif rendah dengan nilai rata-rata 58. Sementara standar kelulusan mahasiswa Program Studi Pendidikan Matematika yang telah ditentukan di Program Studi Pendidikan Matematika FKIP Unismuh Makassar harus lebih besar dari 65, nilai C.

Hal ini juga dipertegas dari hasil wawancara terhadap mahasiswa untuk mengindentifikasi penyebab rendahnya prestasi belajar persamaan diferensial, yaitu : (1) dalam proses pembelajaran tidak cukup hanya dengan menggunakan model dan strategi mengajar saja, tetapi harus dibantu dengan Buku Kerja yang disusun oleh dosen yang bersangkutan yang disesuaikan dengan kurikulum yang ada; (2) mahasiswa kurang memahami manfaat belajar mata kuliah persamaan diferensial; dan (3) mahasiswa hanya mengacu pada keterampilan menyelesaikan soal-soal tanpa dukungan oleh penguasaan atau memahami konsep secara mantap.

Salah satu cara memaksimalkan kegiatan pembelajaran ialah dengan menyusun Buku Kerja. Menurut Suharjono dalam Purwitaningrum \& Suparman (2017), Buku Kerja adalah buku yang digunakan sebagai buku pelajaran dalam bidang studi tertentu. Buku Kerja merupakan buku standar yang disusun oleh pakar dalam bidangnya untuk maksud-maksud dan tujuan instruksional, yang dilengkapi dengan sarana-sarana pengajaran yang serasi dan mudah dipahami oleh para pemakainya di sekolah-sekolah dan perguruan tinggi sehingga dapat menunjang suatu progam pengajaran. Hal ini dipertegas oleh Amri \& Ahmadi (2010) bahwa Buku Kerja merupakan segala bentuk bahan yang digunakan untuk membantu tenaga pengajar atau instruktur dalam melaksanakan kegiatan belajar mengajar di kelas. Buku Kerja digunakan untuk melatih peserta didik untuk mengerjakan soal-soal mengenai bidang tertentu (Rahmawati, 2015).

Buku Kerja merupakan salah satu sumber pengetahuan bagi mahasiswa di perguruan tinggi yang merupakan sarana yang sangat menunjang proses kegiatan belajar mengajar. Buku Kerja sangat menentukan keberhasilan pendidikan mahasiswa di perguruan tinggi. Oleh karena itu, Buku Kerja yang baik dan bermutu menjadi sumber pengetahuan yang dapat menunjang keberhasilan belajar mahasiswa dan dapat membimbing serta mengarahkan proses belajar mengajar di kelas ke arah proses pembelajaran yang bermutu. Buku Kerja yang dirancang sesuai dengan kurikulum yang berlaku serta 
dikembangkan dengan paradigma baru akan mengarahkan proses pembelajaran pada arah yang benar sesuai tuntutan kurikulum dengan paradigma baru tersebut (Sunardjo, Yudhianto, \& Rahman, 2016).

Buku Kerja ditujukan sebagai kelengkapan proses pembelajaran dengan ciri ruang lingkupnya dibatasi kurikulum dan silabus. Buku Kerja ditujukan untuk membantu mahasiswa agar belajar secara kontinu dan terarah. Namun demikian, Buku Kerja ini disusun bukan untuk menggantikan peranan buku referensi maupun pengganti kuliah (Riyadi, 2014). Buku Kerja ini bermanfaat untuk mendukung proses belajar mahasiswa. Menurut Santi Relawati (2017), bagian-bagian dari Buku Kerja yaitu kompetensi, kiat-kiat belajar, catatan, latihan, dan tugas, serta tindak lanjut.

Dalam pembuatan Buku Kerja ada beberapa hal yang harus diperhatikan yang terdiri dari tiga bagian yaitu bagian awal, isi, dan akhir. Bagian awal terdiri dari halaman cover, kata pengantar/prakata, dan daftar isi. Halaman cover berisi tentang judul, pengarang, gambar sampul, dan tahun terbit. Kata pengantar/prakata memuat tujuan/alasan penulisan buku, keunikan buku dibandingkan buku yang telah ada, dan kelompok sasaran. Daftar isi memuat judul bab, sub bab, dan nomor halaman.

Bagian isi adalah materi atau konten utama dan isi dari buku. Bagian ini berisikan bab-bab, dan setiap bab terdiri dari sub bab-sub bab dan pokokpokok bahasan yang menjadi inti naskah buku. Bagian isi juga memuat uraian penjelasan, proses operasional atau langkah kerja dari setiap bab maupun sub bab. Setiap paragraf yang ada merupakan unit terkecil suatu pokok bahasan dan harus saling mendukung dan menjadi suatu kesatuan yang koheren. Akan lebih baik buku-buku tertentu dilengkapi dengan tabel, bagan, gambar, dan ilustrasi dan lain sebagainya. Pada bagian akhir dari Buku Kerja berisi kepustakaan, ada beberapa cara penulisan kepustakaan, namun demi keseragaman dipilih satu dari sekian cara tersebut.

Berdasarkan permasalahan-permasalahan yang telah dijelaskan di atas, maka tujuan yang ingin dicapai pada penelitian ini adalah untuk mengetahui proses pengembangan Buku Kerja persamaan diferensial pada mahasiswa Program Studi Pendidikan Matematika FKIP Unismuh Makassar.

\section{METODOLOGI PENELITIAN}

Jenis penelitian yang digunakan adalah penelitian dan pengembangan (research and development). Menurut Sugiyono (2017), penelitian dan pengembangan ini berada pada level 3 yaitu meneliti dan menguji untuk 
mengembangkan produk yang telah ada, baik dari segi bentuk maupun fungsinya. Penelitian ini menghasilkan produk yang dapat digunakan dalam proses perkuliahan mata kuliah persamaan diferensial pada Program Studi Pendidikan Matematika FKIP Unismuh Makassar berupa Buku Kerja. Penelitian ini dilaksanakan di kampus Universitas Muhammadiyah Makassar tahun pelajaran 2019/2020.

Tahapan penelitian pengembangan ini mengacu pada model pengembangan yang dipaparkan oleh Borg \& Gall. Penelitian mengadaptasi model pengembangan tersebut dengan beberapa modifikasi sehingga menjadi delapan langkah sebagai berikut: (1) pengumpulan informasi, pengumpulan informasi dilakukan dengan menganalisis pembelajaran persamaan diferensial yang selama ini dilaksanakan. Untuk menguatkan temuan, peneliti menyebarkan kuesioner kepada mahasiswa terkait dengan proses pembelajaran. Setelah itu, peneliti mewawancarai mahasiswa terkait temuan dan umpan balik terhadap kuesioner. Hasil pengumpulan informasi digunakan sebagai dasar untuk membuat perencanaan pengembangan Buku Kerja persamaan diferensial; (2) perencanaan, perencanaan dibuat berdasarkan hasil pengumpulan informasi. Peneliti mengembangkan Rencana Pembelajaran Semester (RPS) yang digunakan sebagai dasar penyusunan Buku Kerja. RPS juga digunakan untuk menentukan ruang lingkup materi yang akan dilihat dalam Buku Kerja yang akan dikembangkan. RPS disusun berdasarkan analisis kebutuhan dan telaah kurikulum dengan berpedoman pada panduan penyusunan kurikulum perguruan tinggi Universitas Muhammadiyah Makassar; (3) pengembangan desain produk, desain produk yang dikembangkan berupa Buku Kerja pembelajaran pada mata kuliah persamaan diferensial. Buku Kerja terdiri atas sampul, halaman judul, kata pengantar, daftar isi, pembatas bab, advance organizer, uraian materi, rangkuman, dan latihan. Pengembangan Buku Kerja ini bertolak dari RPS yang telah dirancang sesuai dengan hasil pengumpulan informasi terhadap mahasiswa Program Studi Pendidikan Matematika; (4) validasi desain produk, validasi desain produk dilakukan secara internal sebelum dilakukan uji coba di lapangan. Hal ini dilakukan untuk memastikan bahwa Buku Kerja sudah memenuhi syarat validitas dan kelayakan Buku Kerja; (5) revisi produk, revisi produk dilakukan setelah mendapatkan hasil validasi ahli. Desain produk akan diperbaiki berdasarkan saran dan masukan oleh dosen ahli agar dapat dikembangkan Buku Kerja yang layak untuk digunakan saat penilaian produk di lapangan oleh pengguna; (6) uji coba produk, uji coba produk dilakukan 
melalui pemberian angket kepada mahasiswa untuk mengetahui tingkat kelayakan Buku Kerja yang dikembangkan oleh peneliti. Uji coba ini dilakukan dalam mata kuliah persamaan diferensial pada mahasiswa Program Studi Pendidikan Matematika pada tahun ajaran 2019/2020 dengan skala terbatas; (7) revisi produk, revisi produk dilakukan setelah melakukan uji coba terbatas di lapangan. Revisi dilakukan berdasarkan hasil penilaian mahasiswa agar Buku Kerja dapat digunakan pada mata kuliah persamaan diferensial; dan (8) produksi Buku Kerja, produksi Buku Kerja mata kuliah persamaan diferensial pada Mahasiswa Program Studi Pendidikan Matematika setelah dinyatakan layak digunakan oleh ahli melalui validasi dan uji coba lapangan berupa validasi eksternal dengan revisi demi penyempurnaan Buku Kerja.

Instrumen penelitian yang digunakan berupa kuesioner. Isi dari kuesioner meliputi form penilaian untuk ahli/validator dan juga form penilaian untuk mahasiswa. Kuesioner yang dimaksud adalah pernyataan tertutup yang jawaban setiap indikator telah tersedia dari setiap pernyataan sehingga ahli/validator dan mahasiswa hanya menentukan nilainya saja. Penelitian ini menggunakan dua kuesioner untuk mengumpulkan data pengembangan, yaitu angket rencana pembelajaran semester dan angket Buku Kerja.

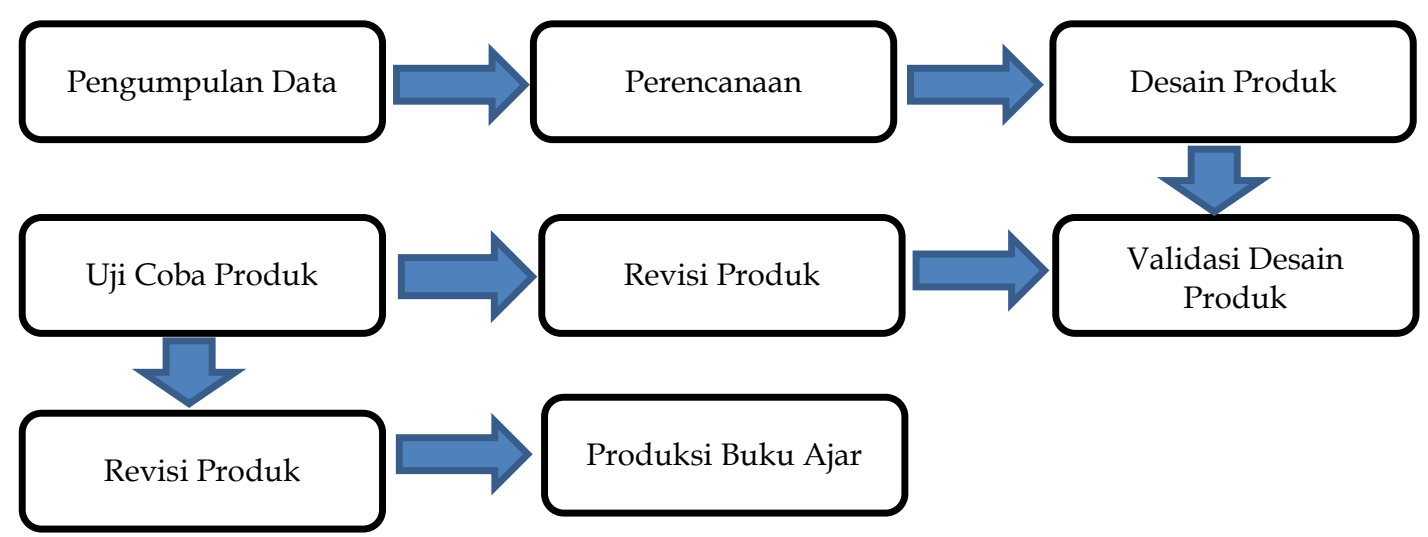

Gambar 1. Desain Model Pengembangan yang Dipaparkan oleh Borg \& Gall

Untuk menjawab tujuan penelitian yang diajukan, maka data dianalisis menggunakan analisis deskriptif. Data hasil validasi para ahli untuk masingmasing perangkat pembelajaran dianalisis dengan mempertimbangkan masukan, komentar, dan saran-saran dari validator. Hasil analisis tersebut dijadikan sebagai pedoman untuk merevisi RPS dan Buku Kerja. Instrumen validasi memiliki 4 pilihan jawaban sesuai dengan pertanyaan. Skor masing- 
masing pilihan jawaban berbeda-beda yang menentukan tingkat validitas RPS dan Buku Kerja, dapat dilihat pada tabel 1.

Tabel 1. Kriteria Validasi

\begin{tabular}{cc}
\hline Skor Validasi & Pilihan Jawaban \\
\hline $\mathbf{3 , 5} \leq \overline{\boldsymbol{X}} \leq \mathbf{4 , 0}$ & Sangat Valid \\
$\mathbf{2 , 5} \leq \overline{\boldsymbol{X}}<\mathbf{3 , 5}$ & Valid \\
$\mathbf{1 , 5} \leq \overline{\boldsymbol{X}}<\mathbf{2 , 5}$ & Cukup Valid \\
$\mathbf{1 , 5} \leq \overline{\boldsymbol{X}}<\mathbf{1 , 5}$ & Kurang Valid \\
\hline
\end{tabular}

Kriteria yang digunakan untuk memutuskan bahwa Rencana Pembelajaran Semester (RPS) dan Buku Kerja memiliki tingkat validitas yang memadai yaitu berada pada kategori "valid". Angket respons mahasiswa memiliki 4 pilihan jawaban sesuai dengan pernyataan. Hasil skor penilaian dari masing-masing siswa dicari rata-ratanya dan dikonversi untuk menentukan kemenarikan. Hasil konversi skor menjadi penilaian terhadap produk Buku Kerja dapat dilihat dalam tabel 2.

Tabel 2. Kriteria untuk Uji Coba

\begin{tabular}{cc}
\hline Skor Kualitas & Pilihan Jawaban \\
\hline $\mathbf{3 , 5} \leq \overline{\mathbf{X}} \leq \mathbf{4 , 0}$ & Sangat Menarik \\
$\mathbf{2 , 5} \leq \overline{\mathbf{X}}<\mathbf{3 , 5}$ & Menarik \\
$\mathbf{1 , 5} \leq \overline{\mathbf{X}}<\mathbf{2 , 5}$ & Cukup Menarik \\
$\mathbf{1 , 0} \leq \overline{\mathbf{X}}<\mathbf{1 , 5}$ & Kurang Menarik \\
\hline
\end{tabular}

\section{HASIL PENELITIAN DAN PEMBAHASAN}

Penelitian dan pengembangan ini bertujuan untuk menghasilkan sebuah produk berupa Buku Kerja persamaan diferensial biasa Program Studi Pendidikan Matematika Fakultas Keguruan dan Ilmu Pendidikan Unismuh Makassar. Buku Kerja ini memfasilitasi mahasiswa dalam proses pembelajaran untuk belajar mandiri. Terdapat dua tahap yang dilaksanakan peneliti dalam menghasilkan produk. Hasil penelitian dan pengembangan akan dipaparkan sebagai berikut:

a. Pengumpulan informasi

Pada tahap ini, peneliti melakukan pengumpulan informasi sebagai langkah awal untuk menentukan masalah dalam pengembangan Buku Kerja persamaan diferensial biasa. Adapun hasil dari langkah awal ini adalah: (1) analisis proses, analisis proses dilakukan dengan melakukan pengamatan 
pada saat pembelajaran berlangsung. Berdasarkan hasil pengamatan ditemukan masalah selama proses pembelajaran, yaitu mahasiswa kurang aktif dan kegiatan belajar mengajar hanya berpusat pada dosen. Hal ini terlihat dari kurang berpartisipasinya mahasiswa dalam pembelajaran. Oleh karena itu, diperlukan suatu produk untuk meminimalisir permasalahan di atas dengan mengembangkan Buku Kerja persamaan diferensial biasa; (2) analisis mahasiswa, analisis mahasiswa dilakukan untuk menelaah aspek kognitif. Kemampuan mahasiswa angkatan 2017 untuk mata kuliah persamaan diferensial biasa masih berada pada kategori sedang pada ujian semester genap 2018/2019. Mahasiswa masih kurang menguasai materi prasyarat seperti mata kuliah kalkulus. Hal ini terlihat dari kemampuan mahasiswa melakukan penurunan dan pengintegralan; (3) analisis mahasiswa, kegiatan pada tahap ini adalah mengidentifikasi dan menyusun materi-materi yang akan dipelajari pada mata kuliah persamaaan diferensial biasa. Dari angket yang diberikan kepada 32 mahasiswa, secara umum mahasiswa mengemukakan kondisi Buku Ajar yaitu: (1) dalam pembelajaran persamaan diferensial biasa, mahasiswa hanya menggunakan satu sumber belajar; (2) buku yang digunakan mahasiswa menggunakan kalimat dan penyelesaian yang sulit dipahami.

\section{b. Perencanaan dan pengembangan desain produk}

Setelah dilakukan pengumpulan informasi melalui wawancara dan observasi lapangan, maka peneliti membuat perencanaan terlebih dahulu. Kegiatan dalam tahap perencanaan adalah merencanakan dan menyusun Buku Kerja yang akan dikembangkan mulai dari penyusunan Rencana Pembelajaran Semester (RPS), produk Buku Kerja, dan penyusunan instrumen penilaian. Kegiatan yang dilakukan adalah: (1) penyusunan Rencana Pembelajaran Semester (RPS), tingkat keberhasilan pembelajaran dimulai dengan perencanaan yang baik, tentunya realisasi kegiatan pembelajaran sesuai rencana yang dibuat. RPS yang dikembangkan dalam, diharapkan kompetensi dalam standar kompetensi kelulusan dapat tercapai. Rencana Pembelajaran Semester (RPS) yang digunakan Prodi Pendidikan Matematika Unismuh Makassar berbasis Kerangka Kompetensi Nasional Indonesia (KKNI). Adapun bagian-bagian dari Rencana Pembelajaran Semester (RPS) adalah profil mata kuliah, deskripsi mata kuliah, Capaian Pembelajaran (CP), bahan kajian (pokok bahasan) dan daftar referensi bahan kajian, metode pembelajaran dan alokasi waktu, pengalaman belajar mahasiswa, serta 
indikator penilaian; (2) penyusunan produk Buku Kerja, Buku Kerja terdiri dari susunan bagian-bagian yang kemudian dipadukan sehingga menjadi sebuah bangunan utuh yang layak disebut sebagai bahan ajar. Oleh karena itu, kita perlu memahami dan mengetahui masing-masing bentuk Buku Kerja tersebut agar bisa membuat berbagai bahan ajar yang baik. Buku Kerja diorganisasikan sesuai dengan tatanan buku pada umumnya. Untuk menjadi sebuah buku dengan satu kesatuan buku yang utuh, maka sebuah Buku Kerja yang layak hendaknya disusun atas dasar struktur yang baik dan rapi. Buku Kerja tersusun atas bagian-bagian yang membangun buku menjadi sebuah struktur bahan cetakan yang layak untuk dibaca dan dikonsumsi oleh khalayak umum ataupun target pembaca yang lebih spesifik. Penulisan Buku Kerja dilakukan sesuai dengan Rencana Pembelajaran Semester (RPS) yang telah dikembangkan. Buku Kerja ini memuat standar kompetensi dan indikator, peta konsep, rangkuman, soal latihan, dan daftar rujukan. Berikut ini akan dilihat secara objektif Buku Kerja terdiri atas 2 komponen, yaitu bagian awal terdiri atas cover (sampul), kata pengantar, daftar isi dan bagian isi terdiri atas judul bab, isi materi, rangkuman, latihan, dan daftar pustaka. Penelitian pengembangan dengan menggunakan adaptasi dari Borg \& Gall, menghasilkan produk berupa Buku Kerja dalam bentuk cetak. Adapun dalam Buku Kerja persamaan diferensial biasa terdiri dari beberapa sub bagian materi; dan (3) penyusunan instrumen penilaian perangkat, instrumen penilaian perangkat pembelajaran disusun dan dikembangkan oleh peneliti berupa kuesioner. Penilaian yang digunakan, menggunakan skala empat. Instrumen penilaian yang disusun meliputi lembar penilaian Rencana Pembelajaran Semester (RPS), lembar penilaian produk Buku Kerja.

c. Validasi desain produk

Pada tahap ini dilakukan beberapa persiapan yang akan mendukung pelaksanaan penelitian. Seperti yang dipaparkan di atas, tahapan ini meliputi validasi instrumen penelitian berupa validasi penyusunan Rencana Pembelajaran Semester (RPS) dan validasi Buku Kerja mata kuliah persamaan diferensial biasa kemudian divalidasi oleh 2 orang validator matematika. Validasi instrumen menggunakan skor penilaian skala empat dengan kategori 4 (baik sekali), 3 (baik), 2 (kurang baik), dan 1 (tidak baik). Penilaian para ahli berarti validator menelaah semua perangkat yang telah dihasilkan. Hasil validasi dari para ahli digunakan sebagai dasar untuk melakukan revisi perangkat pembelajaran. 
Validasi Rencana Pembelajaran Semester (RPS) dilakukan oleh validator untuk menilai validitas rancangan awal, sebelum dilakukan uji coba lapangan. Terdapat 23 pernyataan di dalam validasi penyusunan Rencana Pembelajaran Semester (RPS) yang terbagi atas empat aspek yaitu aspek penyusun RPS yang terdiri dari 5 (lima) pernyataan, aspek isi RPS yang terdiri dari 11 (sebelas) pernyataan, aspek bahasa yang terdiri 4 (empat) pernyataan dan aspek waktu yang terdiri 3 (tiga pernyataan). Hasil validasi Rencana Pembelajaran Semester (RPS) dapat dilihat pada tabel 5.

Tabel 5. Hasil Validasi Rencana Pembelajaran Semeter (RPS)

\begin{tabular}{ccc}
\hline No & Deskriptor & Rata-Rata \\
\hline 1 & Aspek penyusun & 3,50 \\
2 & Aspek Isi & 3,64 \\
3 & Aspek Bahasa & 4,00 \\
4 & Aspek Waktu & 4,00 \\
& Skor Rata-Rata Keseluruhan & 3,78 \\
\hline
\end{tabular}

Berdasarkan tabel 5, secara umum diperoleh nilai rata-rata total validitas Rencana Pembelajaran Semester (RPS) yang diperoleh adalah 3,78. Oleh karena itu, dapat disimpulkan bahwa berdasarkan keseluruhan aspek, Rencana Pembelajaran Semester (RPS) ini dinyatakan memenuhi kriteria validitas, yakni kategori sangat valid dan dapat digunakan dengan sedikit revisi. Berikut ini grafik skor penilaian Rencana Pembelajaran Semester (RPS) yang dilihat pada gambar 2 .

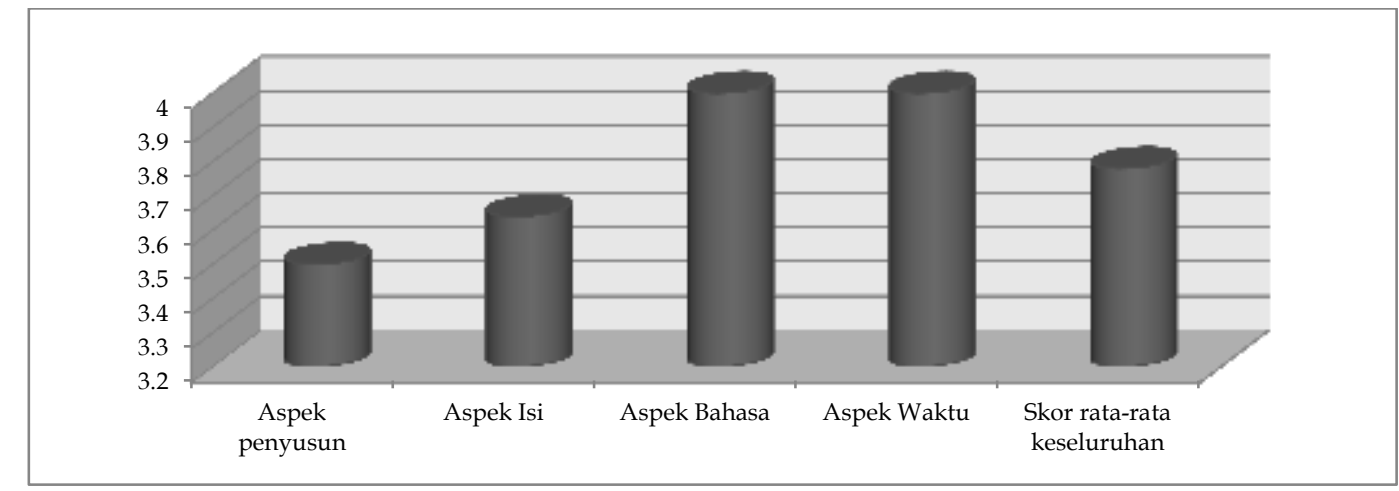

Gambar 2. Grafik Skor Penilaian Rencana Pembelajaran Semester

Selanjutnya validasi dilakukan untuk menguji kelayakan dari segi desain produk Buku Kerja mata kuliah persamaan diferensial biasa. Validasi 
desain produk ini terdiri atas 21 pernyataan yang terbagi atas empat aspek, yaitu aspek desain/sampul yang terdiri dari 6 (enam) pernyataan, aspek penyajian yang terdiri dari 5 (lima) pernyataan, aspek materi yang terdiri dari 6 (enam) pernyataan dan aspek bahasa yang terdiri 4 (empat) pernyataan. Hasil validasi produk Buku Kerja dapat dilihat pada tabel 6.

Tabel 6. Hasil Validasi Produk Buku Kerja

\begin{tabular}{ccc}
\hline No & Deskriptor & Rata-Rata \\
\hline 1 & Aspek Desain/Sampul & 3,58 \\
2 & Aspek Penyajian & 3,40 \\
3 & Aspek Materi & 4,42 \\
4 & Aspek Bahasa & 4,00 \\
& Skor Rata-Rata Keseluruhan & 3,60 \\
\hline
\end{tabular}

Berdasarkan tabel 6, secara umum diperoleh nilai rata-rata total validitas produk Buku Kerja yang diperoleh adalah 3,60. Oleh karena itu, dapat disimpulkan bahwa berdasarkan keseluruhan aspek, produk Buku Kerja ini dinyatakan memenuhi kriteria validitas pada kategori sangat valid, dan dapat digunakan dengan sedikit revisi. Berikut ini grafik skor penilaian Rencana Pembelajaran Semester (RPS) yang dilihat pada gambar 3.

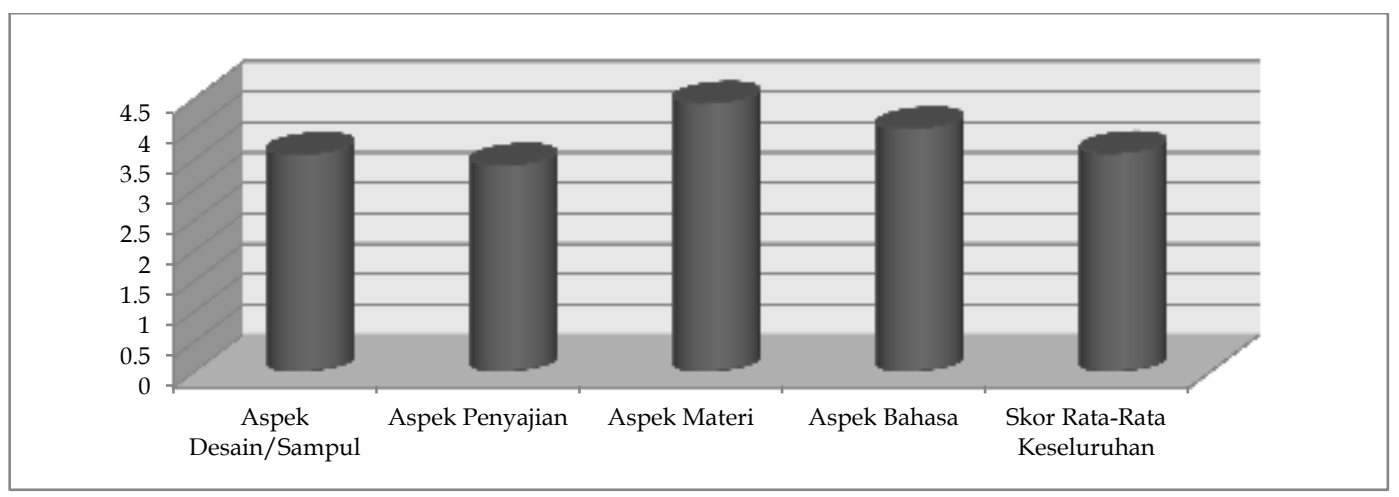

Gambar 3. Grafik Skor Penilaian pada Aspek Bahasa Buku Kerja

d. Revisi produk

Revisi produk merupakan langkah yang ditempuh peneliti setelah dilaksanakan uji validasi terhadap dan Rencana Pembelajaran Semester (RPS) dan Buku Kerja. Ahli atau validator memberikan komentar dan saran secara umum untuk perbaikan desain yang dikembangkan. Setelah dilakukan validasi Rencana Pembelajaran Semester (RPS) oleh ahli yang terbagi atas empat aspek, validator atau ahli memberikan komentar atau saran secara 
umum untuk perbaikan desain Rencana Pembelajaran Semester. Hasil validasi terhadap Rencana Pembelajaran Semester (RPS) dapat dilihat pada tabel 7.

Tabel 7. Komentar dan Saran Hasil Validasi Rencana Pembelajaran Semester

\begin{tabular}{|c|c|c|}
\hline No & Aspek RPS & Komentar dan Saran \\
\hline \multirow[t]{3}{*}{1} & $\begin{array}{l}\text { Aspek } \\
\text { Penyusun }\end{array}$ & $\begin{array}{l}\text { - Seharusnya karakteristik mahasiswa masuk pada } \\
\text { indikator }\end{array}$ \\
\hline & & $\begin{array}{l}\text { - Isi RPS mencerminkan target CPL yang dibebankan } \\
\text { pada mata kuliah }\end{array}$ \\
\hline & & $\begin{array}{l}\text { - Pembelajaran yang dirancang berpusat pada } \\
\text { mahasiswa }\end{array}$ \\
\hline 2 & Aspek Isi & $\begin{array}{l}\text { - Munculkan logo Universitas Muhammadiyah Makassar } \\
\text { - Metode yang dituangkan dalam RPS harus variatif dan } \\
\text { memperhatikan model strategi pembelajaran } \\
\text { - RPS harus jelas sumber rujukan yang digunakan } \\
\text { - Setiap bab memiliki pengalaman belajar yang } \\
\text { diwujudkan dalam bentuk deskripsi tugas }\end{array}$ \\
\hline 3 & $\begin{array}{l}\text { Aspek } \\
\text { Bahasa }\end{array}$ & - Susunan kalimat pada RPS masih kurang tepat \\
\hline 4 & $\begin{array}{l}\text { Aspek } \\
\text { Waktu }\end{array}$ & $\begin{array}{l}\text { - Waktu yang digunakan sesuai dengan kesulitan } \\
\text { indikator tiap bab }\end{array}$ \\
\hline
\end{tabular}

Komentar atau saran dari penilaian validator terhadap Buku Kerja dapat dilihat pada tabel 8.

Tabel 8. Komentar dan Saran Hasil Validasi Buku Kerja

\begin{tabular}{|c|c|c|}
\hline No & $\begin{array}{c}\text { Aspek } \\
\text { RPS }\end{array}$ & Komentar dan Saran \\
\hline 1 & $\begin{array}{l}\text { Aspek } \\
\text { Tampilan/ } \\
\text { Sampul }\end{array}$ & $\begin{array}{l}\text { - Perlu ditambahkan profil program studi pada sampul } \\
\text { - Ukuran font pada judul buku sebaiknya lebih besar } \\
\text { - Pada sampul tetap menggunakan kata Buku Kerja sebagai } \\
\text { produk } \\
\text { - Warna sampul harus lebih menarik }\end{array}$ \\
\hline 2 & $\begin{array}{l}\text { Aspek } \\
\text { Penyajian }\end{array}$ & $\begin{array}{l}\text { - Buku Kerja mengikuti kesesuaian materi ajar dengan CP } \\
\text { pada RPS } \\
\text { - Penyajian harus lebih menarik sehingga meningkatkan } \\
\text { minat baca mahasiswa } \\
\text { - Penggunaan istilah agar lebih konsisten } \\
\text { - Perhatikan simbol-simbol dan penggunaan simbol dalam } \\
\text { Buku Kerja persamaan diferensial biasa }\end{array}$ \\
\hline
\end{tabular}




\begin{tabular}{|c|c|c|}
\hline & & $\begin{array}{l}\text { - Perbaiki tulisan dan tata letak gambar pada Buku Kerja } \\
\text { - Perlu ditambahkan capaian pembelajaran dan indikator } \\
\text { - Rangkuman harus jelas dan padat } \\
\text { - Instrumen latihan setiap bab harus mewakili indikator } \\
\text { yang dicapai setiap standar kompetensi lulusan } \\
\text { - Konsep dalam penyusunan Buku Kerja berdasarkan pada } \\
\text { rencana pembelajaran semester yang telah dibuat }\end{array}$ \\
\hline 3 & $\begin{array}{l}\text { Aspek } \\
\text { Materi }\end{array}$ & $\begin{array}{l}\text { - Contoh persamaan diferensial biasa lebih disesuaikan } \\
\text { dengan konsep dasar persamaan diferensial } \\
\text { - Diperbanyak contoh-contoh yang relevan dengan materi } \\
\text { - Membuat lebih jelas langkah-langkah dalam menentukan } \\
\text { solusi persamaan diferansial. } \\
\text { - Dijelaskan dengan baik dan terstruktur komponen dari } \\
\text { persamaaan diferensial Biasa orde satu } \\
\text { - Definisi dalam Buku Kerja harus didukung dengan } \\
\text { contoh-contoh } \\
\text { - Diharapkan untuk Buku Kerja, dibuatkan latihan mandiri } \\
\text { dibuat pada akhir materi mewakili setiap indikator }\end{array}$ \\
\hline 4 & $\begin{array}{l}\text { Aspek } \\
\text { Bahasa }\end{array}$ & $\begin{array}{l}\text { - Masih terdapat susunan kalimat yang kurang tepat } \\
\text { pada Buku Kerja } \\
\text { - Sebaiknya menggunakan kalimat matematika yang benar } \\
\text { - Kesalahan ketik angka dan simbol perlu diperhatikan } \\
\text { dengan baik }\end{array}$ \\
\hline
\end{tabular}

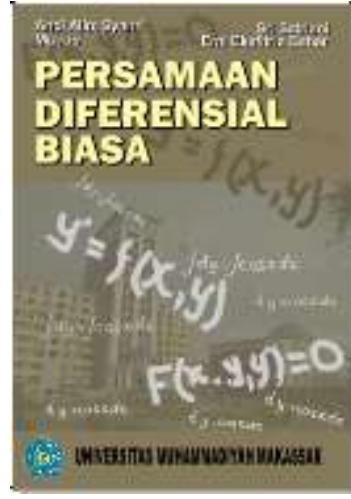

Sebelum Direvisi

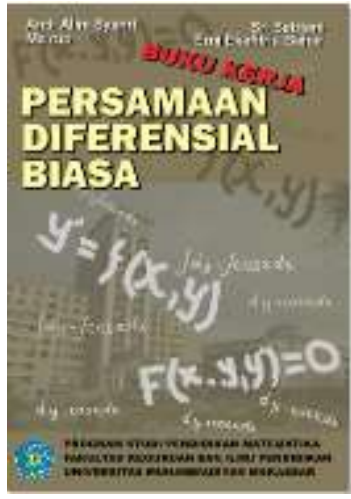

Sesudah Direvisi

e. Uji coba produk

Setelah produk Buku Kerja melalui tahap validasi oleh ahli/validator serta telah selesai diperbaiki, selanjutnya produk diujicobakan kepada mahasiswa. Pada tahap ini, mahasiswa diberi angket yang berisi pernyataan mengenai kesesuaian produk Buku Kerja terhadap materi, desain, penulisan, 
dan motivasi serta kebermanfaatan penggunaan. Angket produk Buku Kerja yang diberikan kepada mahasiswa terdiri dari 21 pernyataan yang terbagi atas empat aspek yaitu aspek desain/sampul yang terdiri dari 6 (enam) pernyataan, aspek penyajian yang terdiri dari 5 (lima) pernyataan, aspek materi yang terdiri dari 6 (enam) pernyataan dan aspek bahasa yang terdiri dari 4 (empat) pernyataan. Data uji coba dapat dilihat pada tabel 9.

Tabel 9. Hasil Uji Coba Produk kepada Mahasiswa Semester VI Program Studi Pendidikan Matematika 2019-2020

\begin{tabular}{ccc}
\hline No & Deskriptor & Rata-Rata \\
\hline 1 & Aspek Tampilan depan/Sampul & 3,43 \\
2 & Aspek Penyajian & 3,56 \\
3 & Aspek Materi & 3,56 \\
4 & Aspek Bahasa & 3,90 \\
& Skor Rata-Rata Keseluruhan & 3,61 \\
\hline
\end{tabular}

Berdasarkan tabel 9, diperoleh hasil uji produk Buku Kerja terhadap 15 mahasiswa diperoleh aspek tampilan depan/sampul diperoleh skor rata-rata sebesar 3,43 dengan kategori menarik, skor rata-rata pada aspek penyajian sebesar 3,56 dengan kategori sangat menarik, skor rata-rata pada aspek materi sebesar 3,56 dengan kategori sangat menarik, skor rata-rata pada aspek bahasa sebesar 3,90 dengan kategori sangat menarik, dan secara keseluruhan diperoleh skor rata-rata sebesar 3,61 dengan kategori sangat menarik. Oleh karena itu, dapat disimpulkan bahwa produk Buku Kerja layak digunakan. Berikut ini grafik skor hasil uji coba produk kepada mahasiswa yang dilihat pada gambar 4 .

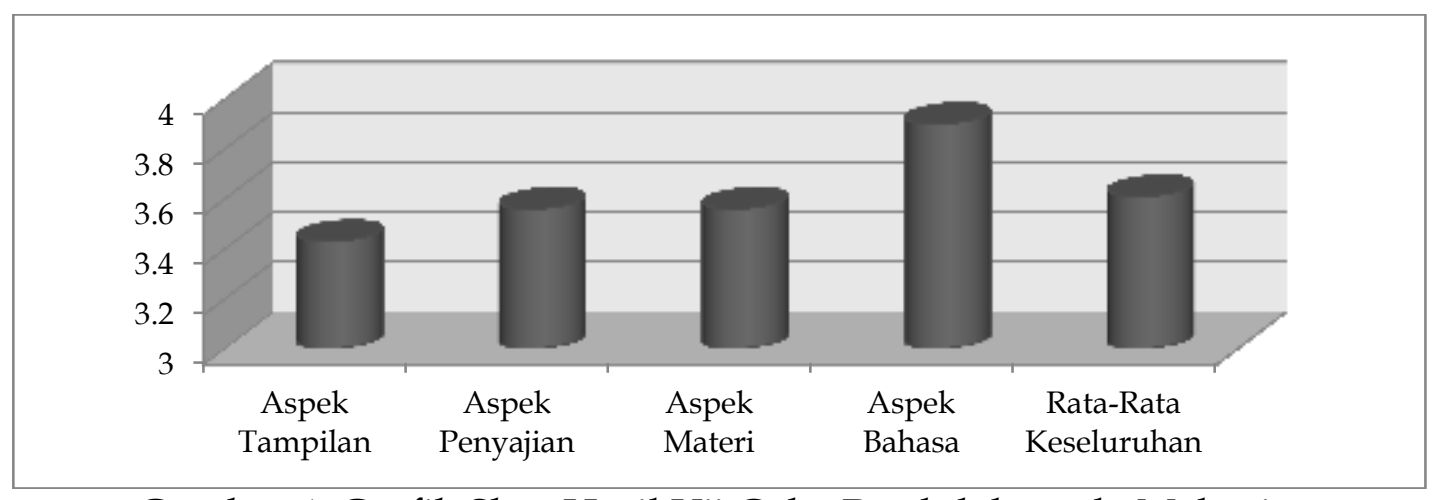

Gambar 4. Grafik Skor Hasil Uji Coba Produk kepada Mahasiswa 
f. Revisi produk

Skor rata-rata kemenarikan produk secara keseluruhan sebesar 3,61 dan berada pada kategori sangat menarik, sehingga dapat disimpulkan bahwa produk Buku Kerja layak digunakan. Berikut ini komentar atau saran dari penilaian mahasiswa, terlihat pada tabel 10.

Tabel 10. Komentar dan Saran Mahasiswa

\begin{tabular}{|c|c|c|}
\hline No & Aspek RPS & Komentar dan Saran \\
\hline 1 & $\begin{array}{l}\text { Aspek } \\
\text { Tampilan/ } \\
\text { Sampul }\end{array}$ & $\begin{array}{l}\text { - Perlu ditambahkan profil program studi pada } \\
\text { sampul } \\
\text { - Ukuran font pada judul pada buku sebaiknya lebih } \\
\text { besar } \\
\text { - Pada sampul tetap menggunakan kata Buku Kerja } \\
\text { sebagai produk } \\
\text { - Warna sampul harus lebih menarik }\end{array}$ \\
\hline 2 & $\begin{array}{l}\text { Aspek } \\
\text { Penyajian }\end{array}$ & $\begin{array}{l}\text { - Penggunaan jenis dan ukuran huruf pada Buku Kerja } \\
\text { harus konsisten } \\
\text { - Pilih jenis huruf yang memotivasi minat baca bagi } \\
\text { pembaca } \\
\text { - Penulisan simbol sebuah definisi harus konsisten }\end{array}$ \\
\hline 3 & Aspek Materi & $\begin{array}{l}\text { - Contoh persamaan diferensial biasa lebih disesuakan } \\
\text { dengan konsep dasar persamaan diferensil } \\
\text { - Diperbanyak contoh-contoh yang relevan dengan } \\
\text { materi } \\
\text { - Membuat lebih jelas langkah-langkah dalam } \\
\text { menentukan solusi persamaan diferansial. } \\
\text { - Dijelaskan dengan baik dan terstruktur komponen } \\
\text { dari persamaaan diferensial biasa orde satu } \\
\text { - Definisi dalam Buku Kerja harus didukung dengan } \\
\text { contoh-contoh } \\
\text { - Diharapkan untuk Buku Kerja, dibuatkan latihan } \\
\text { mandiri dibuat pada akhir materi mewakili setiap } \\
\text { indikator }\end{array}$ \\
\hline 4 & Aspek Bahasa & $\begin{array}{l}\text { - Susunan kalimat pada Buku Kerja masih ditemukan } \\
\text { susunan kalimat yang kurang tepat } \\
\text { - Sebaiknya menggunakan kalimat matematika yang } \\
\text { benar } \\
\text { - Kesalahan pengetikan angka dan simbol perlu } \\
\text { diperhatikan dengan baik }\end{array}$ \\
\hline
\end{tabular}


Revisi produk dilakukan untuk memperbaiki kelemahan yang ada dalam produk yang dikembangkan oleh peneliti. Setelah perbaikan, diperoleh produk akhir atau produk final yang dapat digunakan dalam perkuliahan.

\section{g. Produksi buku kerja}

Sebelum produksi Buku Kerja dilaksanakan, terlebih dahulu direvisi sesuai dengan saran dan kritik dari validator/ahli dan mahasiswa pada uji coba kedua. Buku Kerja yang sudah dibuat dan sudah melewati beberapa kali revisi menjadi pertimbangan peneliti dalam memperbaiki produk Buku Kerja. Berdasarkan saran-saran tersebut, akan diproduksi Buku Kerja yang dapat dipergunakan di lapangan khususnya pada mahasiswa Program Studi Pendidikan Matematika FKIP Universitas Muhammadiyah Makassar.

\section{SIMPULAN}

Berdasarkan penelitian pengembangan Buku Kerja mata kuliah persamaan diferensial biasa yang telah dilakukan, maka diperoleh kesimpulan sebagai berikut: (1) jenis penelitian pengembangan ini menggunakan adaptasi dari model desain pengembangan Borg \& Gall dengan menghasilkan produk Buku Kerja persamaan diferensial biasa untuk mahasiswa semester VI Program Studi Pendidikan Matematika FKIP Universitas Muhammadiyah Makassar. Tahapan yang dilalui, yaitu pengumpulan informasi, perencanaan, pengembangan desain produk, validasi desain produk, revisi produk, uji coba produk, revisi produk, dan produksi Buku Kerja; dan (2) validitas RPS dan Buku Kerja yang dikembangkan dapat diketahui dari hasil penilaian 2 validator. Rencana Pembelajaran Semester (RPS) yang dikembangkan memperoleh nilai rata-rata sebesar 3,78 dan termasuk dalam kategori sangat valid, sedangkan Buku Kerja yang dikembangkan memperoleh nilai rata-rata sebesar 3,60 dan termasuk dalam kategori sangat valid. Rencana Pembelajaran Semester (RPS) dan Buku Kerja dinyatakan memenuhi kriteria validitas, dan menurut para ahli berada pada skala penilaian baik dan dapat digunakan dengan sedikit revisi. Secara keseluruhan, skor rata-rata uji coba produk kepada mahasiswa untuk mengetahui kemenarikan produk Buku Kerja adalah 3,61, berada pada kategori sangat menarik, sehingga disimpulkan bahwa produk Buku Kerja layak digunakan di lapangan khususnya pada mahasiswa program studi pendidikan matematika FKIP Universitas Muhammadiyah Makassar. 


\section{DAFTAR PUSTAKA}

Amri, S., \& Ahmadi, I. K. (2010). Kontruksi pengembangan pembelajaran. Jakarta: PT. Prestasi Pustakaraya.

Ibnas, R. (2017). Persamaan differensial eksak dengan faktor integrasi. Jurnal MSA, 5(2), 91-99. Retrieved from http://journal.uinalauddin.ac.id/index.php/msa/article/viewFile/4514/4124.

Lumbantoruan, J. H. (2019). Pengembangan bahan ajar persamaan diferensial berbasis model brown di program studi pendidikan matematika fakultas keguruan dan ilmu pendidikan Universitas Kristen Indonesia Tahun 2017/2018. Jurnal EduMatSains, 3(2), 147-168.

Purwitaningrum, R., \& Suparman. (2017). Analisis kebutuhan buku ajar matematika berorientasi pendekatan realistik menggunakan model pembelajaran kooperatif. In The 5th Urecol Proceeding (pp. 1205-1210). Retrieved from http://lpp.uad.ac.id/wp-content/uploads/2017/05/21 9-Rahmi-Purwitaningrum1205-1210.pdf.

Rahmawati, G. (2015). Buku teks pelajaran sebagai sumber belajar siswa di SMAN 3 Bandung. EduLib, 5(1), 102-113. https://doi.org/doi.org/10.17 509/edulib.v5i1.2307.

Relawati. (2017). Pengembangan buku kerja berbasis pendekatan analogi pada mata kuliah Kalkulus II di IAIN STS Jambi. Jurnal Ilmiah DIKDAYA, 7(1), 43-54. https:// doi.org/dx.doi.org/10.33087/dikdaya.v7i1.29.

Riyadi, S. (2014). Pengembangan buku kerja berbasis penemuan terbimbing pada perkuliahan geometri ruang di Universitas Mahaputra Muhammad Yamin Solok. Jurnal Fokus, 1-19. Retrieved from http:/ / pspmat.stkipypmbangko.ac.id/wp-content/uploads/2015/10/ 2014_September_JurnalFokus-Sugeng-Riyadi.pdf.

Sugiyarto. (2014). Kalkulus lanjut. Yogyakarta: Binafsi Publisher.

Sugiyono. (2017). Metode penelitan dan pengembangan (research and development/RED). (S. Y. Suryandari, Ed.). Bandung: Alfabeta.

Sunardjo, R. N., Yudhianto, S. A., \& Rahman, T. (2016). Analisis implementasi keterampilan berpikir dasar dan kompleks dalam buku IPA pegangan siswa SMP kurikulum 2013 dan implementasinya dalam pembelajaran. Proceeding Biology Education Conference, 13(1), 133-144. Retrieved from https:/ / media.neliti.com/media/publications/171695-ID-analisisimplementasi-keterampilan-berpi.pdf. 